\title{
Narda (Punica granatum L.) Yeni Nesil Dizileme Teknolojisi Kullanılarak SSR Markırlarının Geliştirilmesi
}

\author{
Özhan Şimşek $^{1^{*}} \quad$ Dicle Dönmez $^{2} \quad$ Burhanettin İmrak $^{3} \quad$ Ahsen Işık Özgüven $^{4} \quad$ Yıldız Aka Kaçar $^{1}$ \\ ${ }^{1}$ Çukurova Üniversitesi, Ziraat Fakültesi, Bahçe Bitkileri Bölümü, Adana \\ ${ }^{2}$ Çukurova Üniversitesi, Biyoteknoloji Uygulama ve Araştırma Merkezi, Adana \\ ${ }^{3}$ Çukurova Üniversitesi, Pozantı Tarımsal Uygulama ve Araştırma Merkezi, Adana \\ ${ }^{4}$ Uluslararası Kıbrıs Üniversitesi, Tarım Bilimleri ve Teknolojileri Fakültesi, Bitkisel Üretim ve Teknolojileri Bölümü, \\ Lefkoşa, Kuzey Kıbrıs
}

Geliş tarihi (Received): 12.10.2018 Kabul tarihi (Accepted): 19.11.2018

\begin{tabular}{ll}
\hline $\begin{array}{l}\text { Anahtar kelimeler: } \\
\text { Mikrosatellit, gen, primer, }\end{array}$ & Özet. Nar çok yıllık, çalı formunda, çok kuvvetli kök sistemine sahip bir subtropik iklim bitkisi olarak \\
DNA & tekrarlanmakta olan $1-6$ bp nükleotid gruplarından oluşmaktadır. Son yıllarda geliştirilen ve \\
& günümüzde en önemli teknolojilerden biri olarak karşımıza çıkan yeni nesil DNA dizileme teknolojileri \\
& yüksek doğrulukla, ultra hızlı dizileme yapabilmektedir. RNA dizileme gen ifadesinin kantitatif analizi \\
& için en güçlü ve yeni teknolojilerden biridir. Bu çalışmada yeni nesil dizileme teknolojileri kullanılarak \\
& narda mikrosatellit bölgelerinin tespit edilmesi amaçlanmıştır. Bu amaçla RNA-seq çalışmaları \\
& yürütülmüştür. RNA-seq analizlerinde 'Hicaznar' ve '33N26' çeşitleri kullanılmıştır. Biyoinformatik \\
& çalışmalar sonucunda DNA üzerinde mikrosatellit bölgelerin tanımlanması sağlanmıştır. Çalışma \\
& sonunda yaklaşık 19,000 mikrosatellit belirlenmiştir. Bu bölgeler arasından rastgele seçilen 20 SSR (Basit \\
& Dizi Tekrarları) primeri çifti 40 farklı nar genotipinde test edilmiştir. Yapılan analizler sonucunda 20 SSR \\
*Sorumlu yazar & primer çiftinden de başarılı bir şekilde amplifikasyon sağlandığı, bunlardan 5 tanesinin polimorfik \\
ozhan12@gmail.com & sonuçlar verdiği tespit edilmiştir. \\
\hline
\end{tabular}

\section{Development of SSR Markers by Using Next Generation Sequencing Technology in Pomegranate (Punica granatum L.)}

\section{Keywords:}

Microsatellite, gene, primer, DNA

\begin{abstract}
Pomegranate is known as a subtropical climate plant with very strong root system, in perennial, bushy form. Microsatellites are composed of 1-6 bp nucleotide groups which are repeated on successive chromosomes of high organisms. New generation DNA sequencing technologies developed in recent years and emerging as one of the most important technologies today can perform highly accurate, ultra-fast sequencing. RNA sequencing is one of the most powerful and new technologies for the quantitative analysis of gene expression. In the present study, it is aimed to identify microsatellite regions in pomegranate by using new generation sequencing technologies. RNA-seq studies have been carried out for this purpose. The 'Hicaznar' and '33N26' varieties were used in RNA-seq analyzes. As a result of the bioinformatics studies, identification of microsatellite regions on DNA has been achieved. Approximately 19,000 microsatellites were determined at the end of the study. 20 SSR primer pairs randomly selected from these regions were tested in 40 different pomegranate genotypes. As a result of the analysis, 20 SSR primer pairs were successfully amplified and 5 of them provided polymorphic results.
\end{abstract}




\section{GiRiş}

Tropik ve subtropik iklim meyvesi olarak bilinmekle birlikte sıcak ve ı ıman iklim bölgelerinde de sınırlı bir şekilde yetişebilen narın dünyada ve ülkemizdeki üretim ve tüketimi her geçen gün artmaktadır. Nar meyveleri özellikle demir, potasyum ve $C$ vitamini içeriği bakımından zengindir. Dünyanın birçok bölgesinde farklı kültürlerde şifalı bitki olarak tedavi amacıyla kullanılmaktadır. Ayrıca nar, çoğaltımı ve bakımı kolay, hastalık ve zararlılara karşı oldukça dayanıklı, erken verime yatan, birim alandan yüksek verim alınan, her yıl düzenli ürün veren, iç ve dış pazarlarda iyi fiyatla satılan, uzun bir raf ömrü olan, taşımaya ve depolamaya uygun önemli bir meyve türüdür (Silva et al., 2013). Bilinen en eski meyve türlerinden biri olan nar, toprak ve iklim koşulları yönünden çok fazla seçici olmaması ve $-10{ }^{\circ} \mathrm{C}$ 'deki düşük sıcaklıklara dayanabilmesinden dolayı geniş bir yayılım alanı göstermektedir (Onur 1982; Yılmaz 2007; Dalka 2010). Narın anavatanları Güney Kafkasya, İran, Afganistan, Güney Asya, Batı Asya, Anadolu ve Akdeniz arasındaki bölgeleri kapsamaktadır. Narın ayrıca, Avrupa ve Afrika'nın Akdeniz sahil bölgelerinde, Çin, Hindistan, Arabistan, Şili, Arjantin, Kaliforniya, Arizona ve Kuzey Meksika'da da yetiştiriciliği yapılmaktadır (Özbek 1977; Dokuzoğuz ve Mendilcioğlu 1978; Onur 1983). Nar ülkemiz için önemli bir meyve türü olarak bilinmektedir. Dünya çapında küçük ölçekte üretimi gerçekleştirilen nar meyvesinin üretimi ve ihracatında ülkemiz ilk sıralarda yer almaktadır. Ülkemiz nar üretimi için oldukça elverişli koşullara sahiptir. Son yıllarda, Türkiye'deki mevcut nar üretim ve ihracat potansiyelinin arttırılması için yeni çeşitlerin geliştirilmesine yönelik çalışmalar önemi ön plana çıkmıştır. Son yıllarda klasik ıslah çalışmaları ile beraber biyoteknoloji çalışmalarının da birçok bitki türünde yürütülen ıslah çalışmalarına adapte edildiği gözlenmektedir. Özellikle moleküler tekniklerin ıslah süreçlerine adapte edilmesi ile sürecin kısaltılması ve erken dönemde bazı özellikler açısından seleksiyon yapılabilmesi mümkün olmaktadır (Şimşek et al., 2017). Son dönemlerde hızla gelişme gösteren moleküler tekniklerin bitki ıslahında kullanımı ile birçok anlamda fayda sağlanabilmektedir. Sözü geçen bu moleküler teknikler arasında kullanım sıklığı oldukça yüksek olan SSR markırları göze çarpmaktadır. Mikrosatellitler yüksek organizmalara ait kromozomlar üzerinde ardışık olarak tekrarlanmakta olan 1-6 bp nükleotid gruplarından oluşmaktadır. SSR tekniğinde genomda tekrarlanan baz dizilerinin bulunduğu bölgeler çoğaltılır. Tekrar sayılarına göre polimorfizm oluşur ve farklı sayıdaki tekrarları temsil eden her bant, farklı bir
2 alleli gösterir. Tekrarlanan DNA'ların sağındaki ve solundaki zincirler o dizine özgüdür, yani spesifiktir. Bu dizinler SSR primerlerini dizayn etmek için kullanılarak belli bir lokus PCR ile klonlanıp çoğaltılır. SSR bir kodominant markır sistemidir. Yani heterozigot alleller homozigotlardan ayırt edilebilir ve PCR kullanımı ile allellerin jel üzerine seperasyonunun yapılmasıyla genom üzerinde belli bölgelerdeki genetik bilgilere ulaşmak mümkündür. Son yıllarda geliştirilen ve günümüzde en önemli teknolojilerden biri olarak karşımıza çıkan yeni nesil DNA dizileme teknolojileri yüksek doğrulukla, ultra hızlı dizileme yapabilme kapasiteleri sayesinde transkriptom analizi, ploidi seviyesinin belirlenmesi, moleküler markır geliştirme ve mRNA profilinin belirlenmesi gibi birçok çalışmada kullanılabilmektedir (Dönmez et al., 2015). RNA dizileme gen ifadesinin kantitatif analizi için en güçlü yeni teknolojilerden biridir. Tipik bir RNA dizileme deneyinde CDNA sentezi ve sonrasında RNA karışımlarından oluşan DNA fragmentlerinin oluşturulması sağlanır. Bir veya iki uca eklenen dizi adaptörleri daha sonra her cDNA fragmentine ilave edilir ve kısa bir dizi yüksek verimli dizileme teknolojisi kullanılarak dizileme gerçekleştirilir. (Wang et al., 2009). Mikrosatellit markırları bitki genetik çalışmalarında en çok bilgi sağlayan DNA tabanlı markır sistemleridir. Fakat SSR markırlarının klasik yöntemler ile geliştirilmesi zordur ve daha yüksek maliyet gerektirmektedir. Yeni nesil dizileme metotlarının en büyük avantajı genom boyunca yayılan ve gen tabanlı olan mikrosatellit lokuslarını içeren çok geniş sekans dataları sunmasıdır. Bu çalışmada, günümüzde moleküler biyoloji alanında son derece önemli hale gelmiş olan yeni nesil dizileme teknolojileri kullanılarak narda mikrosatellit bölgelerinin tespit edilmesi amaçlanmıştır. Bu amaçla RNA-seq olarak bilinen RNA'nın sekanslanmasına dayalı yeni teknoloji ile çalışmalar yürütülmüş ve elde edilen diziler ile gerçekleştirilen biyoinformatik çalışmalar sonucunda DNA üzerinde tekrar eden ve mikrosatellit olarak adlandırılan bölgelerin tanımlanması sağlanmıştır.

\section{MATERYAL VE METOT}

\section{Bitkisel Materyal}

SSR markırlarının geliştirilmesi amacıyla iki farklı nar çeşidinde RNA sekanslama analizleri gerçekleştirilmiştir. RNA-seq analizleri için Çukurova Üniversitesi Ziraat Fakültesi Bahçe Bitkileri Bölümü nar genetik koleksiyonunda yer alan 'Hicaznar' ve '33N26' çeşitleri kullanılmıştır. 


\section{RNA İolasyonu ve RNA'nun Kalite-Miktar Tayini}

RNA-seq analizlerinin gerçekleştirilmesi için ilk olarak 'Hicaznar' ve '33N26' nar çeşitlerine ait örneklerden RNA izolasyonu gerçekleştirilmiştir. RNA izolasyonunda nar için özel olarak geliştirilmiş Zarei et al. (2012)'nin bildirdiği yöntem izlenmiştir. İzole edilen RNA'nın saflığı ve konsantrasyonu Nanodrop spektrofotometre ile ölçülmüştür. RNA sağlamlığı $28 \mathrm{~S}$ ve $18 \mathrm{~S}$ ribozomal RNA alt birimlerinin varlığı ile değerlendirilmiştir. Alt birimlerin varlığı \%1 formaldehit ve etidium bromid agaroz jel elektroforezi ile $312 \mathrm{~nm}$ dalga boyundaki görüntüleme ile tespit edilmiştir.

\section{RNA-seq Analizleri ve SSR Bölgelerinin Belirlenmesi}

Toplam RNA ekstraksiyonunu takiben örneklere DNase I uygulaması yapılmıştır. Ardından oligo(dT)'ler kullanılarak mRNA izolasyonu gerçekleştirilmiştir. İzole edilen mRNA'lar fragmentasyon bufferı ile karıştırılıp fragmante edilmiştir. mRNA fragmentleri template olarak kullanılarak cDNA sentezi gerçekleştirilmiştir. Kısa fragmanlar EB solüsyonu ile saflaştırılmış, ayrıştırılmış ve tek adenin nükleotidi eklenmiştir. Daha sonra kısa fragmanlar adaptörlere bağlanmıştır. PCR amplifikasyonu için uygun fragmentler seçilmiştir. Daha sonra oluşturulan bu kütüphaneler Illumina HiSeq 4000 cihazı kullanılarak sekanslanmıştır.
Sekanslama sonrasında ham okumalar elde edilmiştir. Ilk olarak bilinmeyen baz sıraları $(\mathrm{N})$, adaptör kirliliğinden kaynaklı sıralar ve düşük kaliteli okumalar filtrelenmiş ve net okumalar elde edilmiştir. RNA-seq analizleri BGI bünyesinde gerçekleştirilmiştir.

RNA-seq sonucunda elde edilen tüm transkriptom boyunca mikrosatellit bölgeleri belirlenmiştir. SSR bölgeleri MlcroSAtellite programı (MISA) (http://pgrc.ipk-gatersleben.de/misa/) kullanılarak belirlenmiştir. Belirlenen tekrar bölgelerinin hangi oranlarda di-, tri, tetra-, penta-, hexanükleotidler içerdiği ve tekrar sayıları tespit edilmiştir. Ortaya çıkarılan tekrar bölgelerine dayılı SSR primerleri tasarlanmıştır.

\section{SSR Primerlerinin Test Edilmesi}

RNA-seq analizleri sonucunda elde edilen SSR markırlarından rastgele 20 tanesi, Çukurova Üniversitesi, Ziraat Fakültesi, Bahçe Bitkileri Bünyesinde bulunan 40 adet nar genotipi kullanılarak test edilmiştir. Nar genotiplerinden MiniPrep CTAB yöntemi (Edwards et al., 1991) kullanılarak DNA izolasyonları gerçekleştirilmiştir. DNA'ların kalitesi ve miktarları spektrofotometre ile (NanoDrop ND 100) ölçümler yapılarak belirlenmiştir.

SSR analizlerinde RNA-seq sonuçlarından geliştirilen 20 primer çifti kullanılmıştır. Primerlere ait sekans bilgileri Çizelge 1 'de sunulmuştur.

Çizelge 1. Primerlere ait sekans bilgileri.

Table 1. Sequence information of primers.

\begin{tabular}{llll}
\hline No & Forward Primer & No & Reverse Primer \\
\hline $1 \mathrm{~F}$ & GTTCCATCTTTGTACGAGTCTCA & $1 \mathrm{R}$ & ATGCAAACAAAACACCTGAAGAT \\
$2 \mathrm{~F}$ & AGTTCCATCTTTGTACGAGTCTCA & $2 \mathrm{R}$ & ATGCAAACAAAACACCTGAAGAT \\
$3 \mathrm{~F}$ & TTCCATCTTTGTACGAGTCTCATT & $3 \mathrm{R}$ & ATGCAAACAAAACACCTGAAGAT \\
$4 \mathrm{~F}$ & GTTCCATCTTTGTACGAGTCTCATT & $4 \mathrm{R}$ & ATGCAAACAAAACACCTGAAGAT \\
$5 \mathrm{~F}$ & TCCATCTTTGTACGAGTCTCATT & $5 \mathrm{R}$ & ATGCAAACAAAACACCTGAAGAT \\
$6 \mathrm{~F}$ & GGTCTGATTTGGTTATGATCAGG & $6 \mathrm{R}$ & GTGAGTTGGGTGAGAGAAGAGG \\
$7 \mathrm{~F}$ & GGAGGGTCTGATTTGGTTATGAT & $7 \mathrm{R}$ & GTGAGTTGGGTGAGAGAAGAGG \\
$8 \mathrm{~F}$ & AGATTTCTGAGAACCTGAGGAGG & $8 \mathrm{R}$ & GTGAGAGAAGAGGCCAAACAGAG \\
$9 \mathrm{~F}$ & TTAAATTCTTCCTTCCTGCAACA & $9 \mathrm{R}$ & TTCAGTTGACCTTCACTCACTCA \\
$10 \mathrm{~F}$ & CTTCCTGCAACAATCATTTCTTC & $10 \mathrm{R}$ & TTCAGTTGACCTTCACTCACTCA \\
$11 \mathrm{~F}$ & ATTTTCACCCTTTTCACTTTCGT & $11 \mathrm{R}$ & TTCAGTTGACCTTCACTCACTCA \\
$12 \mathrm{~F}$ & TTAAATTCTTCCTTCCTGCAACA & $12 \mathrm{R}$ & TCAATTCAGTTGACCTTCACTCA \\
$13 \mathrm{~F}$ & TTAAATTCTTCCTTCCTGCAACA & $13 \mathrm{R}$ & TGATGATTAAGGGTGTCAAGGAC \\
$14 \mathrm{~F}$ & TGGATAGTCCAATGCCAGAGTAT & $14 \mathrm{R}$ & TCGGTTGGGTGTATGAGAATATC \\
$15 \mathrm{~F}$ & TGGATAGTCCAATGCCAGAGTAT & $15 \mathrm{R}$ & TTCTTCTCCAAGGAAAAGGAAAG \\
$16 \mathrm{~F}$ & TGGATAGTCCAATGCCAGAGTAT & $16 \mathrm{R}$ & TCTTCTCCAAGGAAAAGGAAAGT \\
$17 \mathrm{~F}$ & CATGCTGGATATTAGCTTCGAGA & $17 \mathrm{R}$ & TCGGTTGGGTGTATGAGAATATC \\
$18 \mathrm{~F}$ & CATGCTGGATATTAGCTTCGAGA & $18 \mathrm{R}$ & GTTCGGTTGGGTGTATGAGAATA \\
$19 \mathrm{~F}$ & ATAAGCATCACAAAATTTCACGG & $19 \mathrm{R}$ & CCCCTCTTTCTTTTTGAAACCTA \\
$20 \mathrm{~F}$ & ATAAGCATCACAAAATTTCACGG & $20 \mathrm{R}$ & TTTCCCCTCTTTCTTTTTGAAAC \\
\hline
\end{tabular}




\section{SSR-PCR Koşulları}

Bitkisel materyallerden izole edilen DNA'lar seyreltilerek sentetik olarak hazırlanmış SSR primerleri ve tüm reaksiyon komponentleri eklenerek "Thermal cycler" içerisine yerleştirilmiştir. PCR reaksiyonu toplam $20 \mu \mathrm{l}$ (25 ng DNA, 2X PCR master mix, $2.5 \mathrm{mM}$ $\mathrm{MgCl}_{2}, 2 \mu \mathrm{mol}$ primer (ileri+geri), 0.8 ünite Taq DNA polimeraz, $5 \mu \mathrm{l} d \mathrm{dH}_{2} \mathrm{O}$ ) olacak şekilde hazırlanmıştır. PCR amplifikasyonu; ilk denatürasyon aşaması $3 \mathrm{dk} .95$ ${ }^{\circ} \mathrm{C}$, daha sonra $1 \mathrm{dk} 95{ }^{\circ} \mathrm{C}, 1 \mathrm{dk} 55^{\circ} \mathrm{C}, 1 \mathrm{dk} .72{ }^{\circ} \mathrm{C}$ (35 döngü) ve $5 \mathrm{dk} 72{ }^{\circ} \mathrm{C}$ son polimerizasyon olacak şekilde gerçekleştirilmiştir.

\section{Li-Cor için Poliakrilamide Jel Hazırlığı ve Elektroforez Koşulları}

Laboratuvar çalışması sonucunda elde edilen PCR ürünlerini koşmak amacıyla \%6.5 poliakrilamide jel hazırlanmıştır. Jel polimerizasyonu tamamlandıktan sonra aparat Li-Cor Elektroforez cihazına yerleştirilmiştir. Cihazda, $1000 \mathrm{~V}, 35 \mathrm{~mA}, 25 \mathrm{~W} 45^{\circ} \mathrm{C}$ 'de yaklaşık $30 \mathrm{dk}$. ön ısıtma yapılmıştır. Ardından eşit miktarda formamide yükleme bufferı eklenmiş ve $P C R^{\prime}$ da $95{ }^{\circ} \mathrm{C}$ de $4 \mathrm{dk}$ denatüre edilen örneklerden $1 \mu \mathrm{l}$ jel'e pipet yardımıyla yüklenmiştir. Daha sonra $1500 \mathrm{~V}$, $35 \mathrm{~mA}, \quad 50 \quad \mathrm{~W} \quad 48{ }^{\circ} \mathrm{C}$ koşullarında 1.5 saat koşturulmuştur.

\section{Sonuçların Değerlendirilmesi}

SSR analizleri sonucunda elde edilen DNA bant profilleri karşılaştırılarak değerlendirilmiştir. Nar genotiplerinden her primer çifti için elde edilen toplam DNA bant profilleri ve polimorfik DNA bant profilleri sayılarak polimorfizm oranları hesaplanmıştır.

\section{BULGULAR VE TARTIŞMA}

Çalışmada kullanılan 'Hicaznar' ve '33N26' çeşitlerine ait örneklerden elde edilen RNA'lar Illumina HiSeq 4000 cihazı kullanılarak sekanslanmıştır. RNA dizilemesi gerçekleştirilen örneklerde $45.24 \mathrm{Mb}$ uzunluğunda toplam ham okuma yapılmıştır. Örneklerden toplam 45 milyon baz uzunluğunda temiz okuma elde edilmiştir. Çalışmada kullanılan tüm örneklerde \%99'un üzerinde temiz okuma tespit edilmiştir. RNA-seq analizlerinde elde edilen okuma verilerine ait bilgiler Çizelge 2'de sunulmuştur.

Okumalar filtrelendikten sonra, temiz okumalar ile de novo analizlerini gerçekleştirmek için Trinity programı kullanılmıştır. Transkriptlerin kalite ölçütleri Çizelge 3'te gösterilmiştir. Örneklerde 48 binin üzerinde transkript elde edilmiştir.

\section{Mikrosatellit Bölgelerinin Belirlenmesi}

RNA-seq analizleri sonucunda iki farklı nar çeşidinde gerçekleştirilen de novo analizleri ile genom üzerinde tekrar eden bölgeler tespit edilmiştir. Yapılan incelemeler sonucunda tekrar bölgeleri içerdiği tekrar motiflerine göre sınıflandırıımıştır. Çalışma sonucunda elde edilen SSR tekrar sayıları ve motifleri Şekil 1'de sunulmuştur.

RNA-seq analizleri sonucunda nar bitkisi için tekrar sayıları ve motifleri belirlenmiştir. Yapılan tespitler sonucunda en yüksek tekrar motifinin 11.758 ile dinükleotid olduğu tespit edilmiştir. Ayrıca Şekil 1'den de görüleceği gibi 38-11758 arasında değişen sayıda farklı tekrar motifleri ortaya çıkarılmıştır.

Çizelge 2. RNA-seq analizlerinde elde edilen okuma verilerine ait bilgiler.

Table 2. Reading data information obtained from RNA-seq analysis.

\begin{tabular}{lcccccc}
\hline \multirow{2}{*}{ Örnek } & $\begin{array}{c}\text { Toplam Ham } \\
\text { Okuma (Mb) }\end{array}$ & $\begin{array}{c}\text { Toplam Temiz } \\
\text { Okuma (Mb) }\end{array}$ & $\begin{array}{c}\text { Toplam Temiz } \\
\text { Baz Sayısı (Gb) }\end{array}$ & $\begin{array}{c}\text { Temiz Okuma Q20 } \\
\text { (\%) }\end{array}$ & $\begin{array}{c}\text { Temiz Okuma } \\
\text { Q30 (\%) }\end{array}$ & $\begin{array}{c}\text { Temiz Okuma } \\
\text { Oranı (\%) }\end{array}$ \\
\hline 33N26 & 45.24 & 45.14 & 4.51 & 97.23 & 93.13 & 99.78 \\
Hicaznar & 45.24 & 45.14 & 4.51 & 97.65 & 93.9 & 99.78 \\
\hline
\end{tabular}

Çizelge 3. Transkriptlerin kalite ölçütleri.

Table 3. Quality criteria of transcripts.

\begin{tabular}{lccccccc}
\hline Örnek & $\begin{array}{c}\text { Toplam } \\
\text { Sayı }\end{array}$ & $\begin{array}{c}\text { Toplam } \\
\text { Uzunluk }\end{array}$ & $\begin{array}{c}\text { Ortalama } \\
\text { Uzunluk }\end{array}$ & N50 & N70 & N90 & GC (\%) \\
\hline 33N26 & 48.996 & 53.228 .009 & 1.086 & 1.812 & 1.252 & 471 & 46.84 \\
Hicaznar & 54.011 & 60.085 .573 & 1.112 & 1.869 & 1.288 & 486 & 46.55 \\
\hline
\end{tabular}




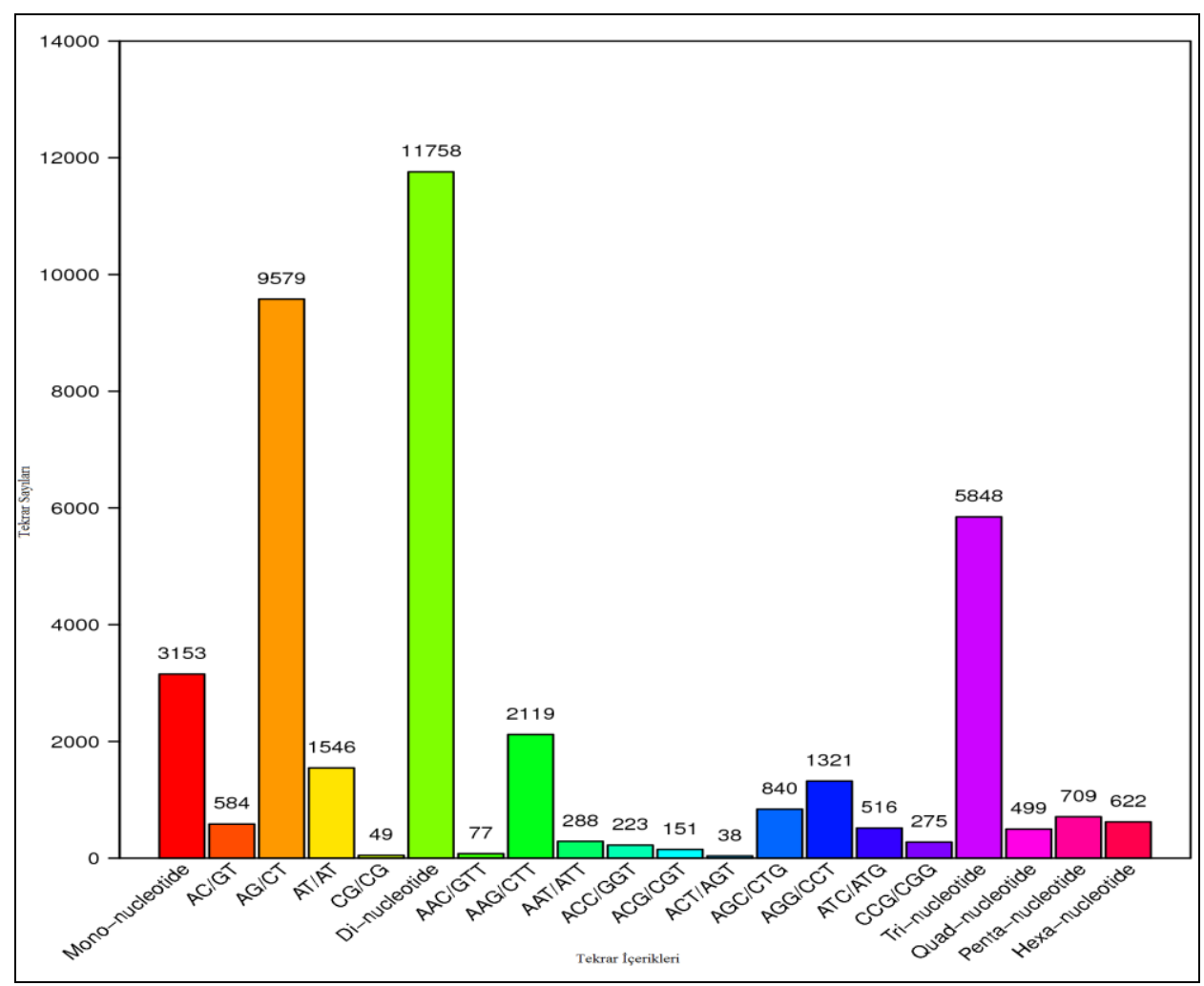

Şekil 1. RNA-seq analizleri sonucunda tespit edilen tekrar sayıları ve tekrar motifleri.

Figure 1. Repetition numbers and repetition patterns determined by RNA-seq analysis.

RNA-seq analizleri sonucunda tasarlanan primerlerden rastgele seçilen 20 tanesi ile SSR analizleri gerçekleştirilmiştir. SSR analizlerinde, Çukurova Üniversitesi Ziraat Fakültesi Bahçe Bitkileri Bölümü'ne ait nar parselinden seçilen 40 nar genotipi kullanılmıştır. SSR analizleri sonucunda nar çeşitlerine ait DNA bant profilleri incelenmiştir. SSR analizlerinde kullanılan 20 primer çiftinin tamamından başarıyla amplifikasyon sağlanmıştır. Bu primerlerden 5 tanesi polimorfik sonuçlar vermiştir. SSR primerlerinden elde edilen DNA bant profili bilgileri Çizelge 4.'te sunulmuştur.

Ülkemiz için oldukça yüksek bir potansiyele sahip olan nar bitkisinde kısıtlı sayıda SSR markırı bulunmaktadır. Bu çalışma ile nar için yeni nesil dizileme teknolojileri kullanılarak birçok SSR markırı geliştirilmiştir. Çalışma kapsamında yalnızca dinükleotid tekrarı içeren toplam 11758 mikrosatellit bölgesi tespit edilmiştir. Di-nükleotid tekrarlarından başka 7678 mikrosatellit bölgesinin varlığı belirlenmiştir.
Çizelge 4. SSR primerlerinden elde edilen DNA bant profili bilgileri.

Table 4. Information of DNA band profiles obtained from SSR primers.

\begin{tabular}{cccc}
\hline $\begin{array}{c}\text { Primer } \\
\text { No }\end{array}$ & $\begin{array}{c}\text { Toplam } \\
\text { bant sayısı }\end{array}$ & $\begin{array}{c}\text { Polimorfik } \\
\text { bant sayısı }\end{array}$ & $\begin{array}{c}\text { Polimorfizm } \\
\text { oranı }\end{array}$ \\
\hline 1 & 3 & 2 & 66.66 \\
2 & 1 & 0 & 0 \\
3 & 4 & 3 & 75 \\
4 & 3 & 2 & 66.66 \\
5 & 1 & 0 & 0 \\
6 & 1 & 0 & 0 \\
7 & 1 & 0 & 0 \\
8 & 1 & 0 & 0 \\
9 & 1 & 0 & 0 \\
10 & 1 & 0 & 0 \\
11 & 1 & 0 & 0 \\
12 & 1 & 0 & 0 \\
13 & 1 & 0 & 0 \\
14 & 1 & 0 & 0 \\
15 & 1 & 0 & 0 \\
16 & 1 & 0 & 0 \\
17 & 2 & 2 & 100 \\
18 & 2 & 2 & 100 \\
19 & 2 & 0 & 0 \\
20 & 1 & 0 & 0 \\
\hline
\end{tabular}


Yeni nesil dizileme teknolojileri yaygınlaşmadan önce klasik yöntemlerle SSR primerlerinin tasarlanması çalışmaları yürütülmüştür. Ancak, bu klasik yöntemlerde geliştirilen markır sayıları kısıtlı kalmıştır. Pirseyedi et al. (2010), narda SSR markırları geliştirerek moleküler karakterizasyon çalışmaları gerçekleştirmişlerdir. SSR markırları geliştirme stratejisi olarak 2'li ve 3'lü nükleotid tekrarlarını içeren hibridizasyon problarını kullanmışlar ve toplam 12 SSR primeri geliştirmişlerdir. Sonuç olarak araştırıcılar geliştirdikleri SSR markırlarının nar genetik çeşitliliği çalışmalarında kullanılabileceğini belirtmişlerdir. Çalışmamız kapsamında ise toplam yaklaşık 19000 SSR bölgesi tanımlanmıştır. Bunlar arasından seçilen 20 tanesi de test edilmiştir. Bu testleme sonucunda 5 primer çiftinin polimorfik sonuçlar verdiği ve narda kullanılabileceği belirlenmiştir. Diğer 15 primer çiftinde ise başarılı bir şekilde amplifikasyon elde edilmesine rağmen kullanılan nar genotipleri açısından bir polimorfizm olmadığı tespit edilmiştir. Bunun sebeplerinden biri kullandığımız bitkisel materyalin dar bir genetik çeşitliliğe sahip olması şeklinde açıklanabilir. Farklı bir çalışmada ise, nar bitkisi için 11 SSR markırı geliştirilmiştir. Çalışmada farklı tekrar içeriklerine sahip problar ile hibridizasyon çalışmaları yürütülmüştür. Geliştirilen 11 mikrosatellit primerleri Tunus'tan örneklenen 27 nar genotipinde denenmiştir. Çalışma sonucunda geliştirilen primerlerin genetik ilişki, DNA parmak izi çalışmalarında kullanılabileceğini belirtilmiştir (Hasnaoui et al., 2010).

Curro et al. (2010), nar için mikrosatellit-AFLP tekniğini kullanarak 9 SSR markırı geliştirmişlerdir. SSR markırlarının kullanışlılığını tespit etmek için toplam 33 nar genotipinde DNA çalışmaları yürütmüşlerdir. Çalışma sonucunda geliştirilen SSR markırlarının, daha önce yürütülen çalışmalarda olduğu gibi düşük polimorfizm gösterdiği bildirilmiştir. Araştırıcılar tespit ettikleri düşük polimorfizm oranının, genotipler arasındaki dar genetik çeşitlilik ile ilgili olabileceğini belirtmişlerdir. Diğer bir çalışmada benzer olarak narda SSR markırları geliştirilmiştir. Çalışmada, toplam 117 mikrosatellit lokusu geliştirmişler ve bu markırların kullanılabilirliği 11 nar genotipinde test edilmiştir. Çalışmada geliştirilen 117 primerin 66'sının polimorfik, 38'inin monomorfik, geriye kalan 13 primerin ise istenilen amplifikasyonu sağlamadığı tespit edilmiştir (Soriano et al., 2011). Mevcut çalışmamız kapsamında oldukça yüksek sayıda SSR bölgesi tespit edilmiştir. Bu bölgelerin ileride yürütülecek birçok moleküler çalışmada kullanılmasının önü açılmıştır.

Bu çalışma narda bu amaçla yürütülen en kapsamlı çalışmalardan bir tanesi olmuştur. Yeni nesil dizileme teknolojilerinin birçok avantajı bulunmaktadır. RNA- seq tekniği, dizileme teknolojisinin kullanımı ile transkriptomların belirlenmesinde kullanılan bir yöntemdir. Bu yöntem kullanılarak yapılan çalışmalar, ökaryotik transkriptomlara bakışı değiştirmiştir. RNAseq yöntemi, diğer yöntemlere göre transkriptlerin izoformlarının seviyelerinin çok daha hassas ölçümünü sağlar. RNA-seq tekniği yüksek düzeyde DNA sekanslamayı, transkriptomların ileri analizini, SSR/SNP tespiti ve haritalamayı mümkün kılmaktadır. RNA sekanslama tekniği şu ana kadar ortaya atılan diğer bütün tekniklerden daha üst bir ökaryotik transkriptom analizi ortaya koymaktadır. Çalışma kapsamında da RNA-seq çalışmaları ile çok yüklü dizi bilgisi sağlanmıştır. Bu dizilerde tekrar bölgeleri taranarak 19,000'in üzerinde SSR markırı geliştirilmiştir. Yeni nesil dizileme teknolojileri kullanılarak farklı bitki türlerinde de SSR markırı geliştirme çalışmaları yürütülmüştür. Zhang et al. (2012), yer fıstığı bitkisinin tohum gelişimi sürecinde transkriptom karakterizasyonu, de novo analizleri ve SSR markır geliştirme çalışmaları yürütmüşlerdir. Bu amaçla, 3 yer fıstığı çeşidinin olgunlaşmamış tohumlarını kullanarak RNA-seq analizleri gerçekleştirmişlerdir. Toplam 100 bp'den oluşan 27 milyonluk okuma gerçekleştirmişler ve 59.077 unigen belirlemişlerdir. Çalışma sonucunda toplam 3.919 mikrosatellit markırı geliştirmişler ve 160 tanesini kontrol etmişlerdir. Farklı bir çalışmada, muzda (Musa balbisiana) yeni nesil dizileme teknolojisi kullanarak transkriptom analizleri kullanılarak SSR markırları geliştirilmiştir. RNA-seq analizlerinde Ion Torrent platformunu kullanarak yaklaşık 4.5 milyon okuma gerçekleştirilmiştir. Biyoinformatik analizler sonucunda ortalama uzunluğu 113 bp olan 82413 transkript tespit edilmiştir. Transkriptlerin Swiss-Prot veri bankasında yapılan araştırmaları sonucunda 35783 transkript belirlenmiştir. Çalışma sonunda toplam 4780 SSR bölgesi tespit edilmiş ve toplam 2628 SSR primeri tasarlanmıştır. Bu primerler arasından rastgele seçilen 30 tanesinin etkinliği muz genotiplerinde araştırılmıştır (Backiyarani et al., 2015).

\section{SONUÇ}

$\mathrm{Bu}$ araştırmada RNA-seq çalışmaları sonucunda 'Hicaznar' ve '33N262' nar çeşitlerine ait örneklerden elde edilen RNA'lar Illumina HiSeq 4000 cihazı kullanılarak sekanslanmıştır. RNA dizilemesi gerçekleştirilen örneklerde 45.24 Mb uzunluğunda toplam ham okuma yapılmıştır. Örneklerden toplam 45 milyon baz uzunluğunda temiz okuma elde edilmiştir. Çalışmada kullanılan tüm örneklerde \%99'un üzerinde temiz okuma tespit edilmiştir. De novo analizleri sonucunda '33N26' çeşidinde 48.996, 
'Hicaznar' çeşidinde ise 54.011 transkript tespit edilmiştir. Dizileme çalışmaları sonucunda yaklaşık olarak 19,000 SSR bölgesi tespit edilmiştir. Sonuç olarak, iki farklı nar çeşidi kullanılarak RNA-seq çalışmaları yürütülmüş ve toplam 19,000 civarında tekrar bölgesi belirlenmiştir. Bu bölgeler arasından rastgele seçilen 20 SSR primeri çifti 40 farklı nar genotipinde test edilmiştir. Yapılan analizler sonucunda 20 SSR primer çiftinden de başarılı bir şekilde amplifikasyon sağlandığı, bunlardan 5 tanesinin polimorfik sonuçlar verdiği tespit edilmiştir. RNA-seq çalışmaları sonucunda tespit edilen SSR primer çiftlerinin ileride yürütülecek DNA parmak izi ve genetik haritalama çalışmalarında kullanılabilmesinin önü açılmıştır.

\section{TEŞEKKÜR}

Bu çalışma Çukurova Üniversitesi Bilimsel Araştırma Projeleri Birimi tarafından desteklenmiştir (Proje no: FBA-2016-5363).

\section{KAYNAKLAR}

Backiyarani S., Uma, S., Saraswathi, MS., Saravanakumar, AS and Chandrasekar A., 2015. Transcriptome Analysis of banana (Musa balbisiana) Based on next-generation sequencing technology. Turkish Journal of Agriculture and Forestry, 39(5): 705-717.

Curro S., Caruso M., Distefano G., Gentile A and La Malfa S., 2010. New microsatellite loci for pomegranate, Punica granatum (Lythraceae). American Journal of Botany, 97: 58-60.

Dalka Y., 2010. Hicrannar ve Canernar Nar (Punica granatum L.) çeşitlerinde çiçeklenme döneminin meyve tutumu, pomolojik özellikler ve kalite üzerine etkisi. Yüksek Lisans Tezi, Gaziosmanpaşa Üniversitesi Fen Bilimleri Enstitüsü, Tokat.

Dokuzoğuz M ve Mendilcioğlu K., 1978. Ege Bölgesi nar çeşitleri üzerinde pomolojik çalışmalar. Ege Üniversitesi Ziraat Fakültesi Dergisi, 15(12): 133-159.

Dönmez D., Şimşek Ö ve Aka Kaçar Y., 2015. Yeni nesil DNA dizileme teknolojileri ve bitkilerde kullanımı. Türk Bilimsel Derlemeler Dergisi, 8(1): 30-37.

Edwards K., Johnstone C and Thompson C., 1991. A Simple and rapid method for the preparation of plant genomic DNA for PCR analysis. Nucleic Acids Research, 19(6): 1349.
Hasnaoui N., Mars M., Chibani J and Trifi M., 2010. Molecular polymorphisms in Tunisian pomegranate (Punica granatum L.) as revealed by RAPD fingerprints. Diversity, 2(1): 107-114.

Onur C., 1983. Akdeniz Bölgesi Narlarının Seleksiyonu, Alata Bahçe Kültürleri Araştırma Eğitim Merkezi, Yayın No, 46, Antalya.

Onur C., 1982. Akdeniz Bölgesi narlarının seleksiyonu. Doktora Tezi, Çukurova Üniversitesi Fen Bilimleri Enstitüsü, Adana.

Özbek S., 1977. Genel Meyvecilik. Çukurova Üniversitesi Ziraat Fakültesi Yayınları, 111. Adana.

Pirseyedi SM., Valizadehghan S., Mardi M., Ghaffari MR., Mahmoodi P., Zahravi M., Zeinalabedini M and Nekoui SMK., 2010. Isolation and characterization of novel microsatellite markers in pomegranate (Punica granatum L.). International Journal of Molecular Sciences, 11: 2010 2016.

Silva JAT., Meshram DT., Narzary D., Ranade SA., Rana TS and Verma N., 2013. Pomegranate biology and biotechnology: A review. Scientia Horticulturae, 160: 85107.

Şimsek O., Donmez D and Kacar YA., 2017. RNA-Seq analysis in fruit science: A review. American Journal of Plant Biology, 2: 1-7.

Soriano JM., Zuriaga E., Rubio P., Llácer G., Infante R and Badenes ML., 2011. Development and characterization of microsatellite markers in pomegranate (Punica granatum L.). Molecular Breeding, 27(1): 119-128.

Wang L., Feng Z., Wang X., Wang X and Zhang X., 2009. DEGseq: An $R$ package for Identifying differentially expressed genes from RNA-Seq data. Bioinformatics, 26(1): 136-138.

Yilmaz C., 2007. Nar. Hasad Yayıncılık, İstanbul.

Zarei A., Zamani Z., Mousavi A., Fatahi R., Alavijeh MK., Dehsara B and Salami SA., 2012. An effective protocol for isolation of high-quality RNA from pomegranate seeds. Asian and Australasian Journal of Plant Science and Biotechnology, 6: 32-7.

Zhang J., Liang S., Duan J., Wang J., Chen S., Cheng Z., Zhang Q., Liang $X$ and Li Y., 2012. De novo assembly and characterisation of the transcriptome during seed development, and generation of Genic-SSR markers in peanut (Arachis hypogaea L.). BMC Genomics, 13(90): 1 6. 